\title{
ANALYSIS OF ECOLOGY OF A LITTLE KNOWN WHITE OAK QUERCUS POLYCARPA SCHUR, USING GEOBIOCOENOLOGICAL TYPOLOGY
}

\author{
RADIM MATULA \\ Mendel University in Brno, Faculty of Forestry and Wood Technology, Department of \\ Forest Botany, Dendrology and Geobiocoenology, Zemědělská 3,616 00 Brno, Czech \\ Republic, radimmatula@hotmail.com
}

Received: $26^{\text {th }}$ August 2009, Accepted: $1^{\text {st }}$ February 2010

\begin{abstract}
Quercus polycarpa Schur is a little known oak species of the Sessile Oak aggregate (Quercus petraea s. lat.). Different habitats were studied using geobiocoenological typology system in order to investigate its ecology. In total, 65 experimental plots were set in forest stands with $Q$. polycarpa in the main storey in 12 protected areas situated in southeast of the Czech Republic. Ecological conditions, basic tree parameters and representation of $Q$. polycarpa within other oak species were evaluated on each plot. The mean values of height, height of life crown setting, stem and crown diameter were related to sub-categories of geobiocoenological system and compared by one-way ANOVA and Scheffé post-hoc test. It has been found out that $Q$. polycarpa grow in a high number in the 2 nd altitudinal zone. It often occurs in a variety of habitats with different hydric and trophic conditions. As expected, the lowest values of measured parameters were found in the dry hydric range, this species reaches the highest values in the normal hydric and mesic ranges.
\end{abstract}

Key words: Quercus polycarpa, ecological requirements, altitudinal zone, hydric range, trophic range

\section{INTRODUCTION}

The genus Quercus comprises approximately 531 species of trees and shrubs (Govaerts and Frodin 1998) distributed throughout much of the Northern Hemisphere (Nixon 1993). Oaks are conspicuous members of the temperate deciduous forests of North America, Europe, and Asia, in addition to being important evergreen elements of Mediterranean woodlands and subtropical forests (Manos et al. 1999; Nixon 2002).

Species of the Quercus genus are among the most valuable woody trees in the Czech Republic representing $6.7 \%$ of the total forest tree composition (MZe 2008). Oaks frequently dominate in forests of the first and the second altitudinal vegetation zones; in the third altitudinal vegetation zone they are usually accompanied by European beech (Fagus sylvatica L.) (Buček and Lacina 1999). They can be also found in higher altitudes, however, they are very rare there (Koblížek 1990).

Quercus polycarpa Schur is a species that resembles $Q$. petraea sensu stricto and from which it is not mostly distinguished and is usually included in the aggregate of $Q$. petraea sensu lato. It was described for the first time by Schur back in 1851 (Schwarz 1936) but 
there is still little information about it. There is no general agreement about its taxonomic status among botanists, since great intraspecific morphological variation makes them difficult to distinguish, however, in many floras of countries in Central, Eastern and SouthEastern Europe it is listed as a separate taxon (Koblížek 1990; Magic 2006; Josipovič 1970; Gancev and Bondev 1966).

$Q$. polycarpa is a tree up to $30 \mathrm{~m}$ high with markedly petiolate leaves; its lamina is elliptic or obovate, sinuous or shallowly lobate, tough. Acorn cups are very important for its identification. They are semi-globular with tough sides, on the whole exterior with coarse scales. The scales are widely ovate with pointed apex, pilose, bald on the back, reddish brown (Koblížek 1990).

Schwarz (1936) and Gančev and Bondev (1966) situated its natural occurrence to SouthEastern Europe and South-Western Asia. Later, Matyas (1970) proved its presence in Hungary followed by Magic (1974) who found it further north in Slovakia and by Kobližek (1990) who discovered Q. polycarpa in the warmest parts of the Czech Republic. Požgaj and Horvátová (1986) suppose its occurrence even further to the north in Poland.

Some notes on its natural habitats and ecology have been published before (Požgaj and Horváthová 1986; Cvjetican and Paunović 1988; Majer 1989; Jovanovič 2000) but an indepth study is still missing. In general, it is considered to be a drought-tolerant species that tends to grow in thermophilic and acid oak forests (Jovanovič 2000; Úradníček et al. 2001). In terms of global warming it seems to be a perspective forestry tree for the future since it is capable to stand more extreme weather conditions with hot and dry summers and cold winters than sessile and common oaks are able to (Koblížek 1990).

In this paper the representation and ecology of $Q$. polycarpa in natural forests are evaluated. The study was aimed to find out how the species differs in representation as well as in basic features such as the height and breast height diameter $\left(\mathrm{d}_{1,3}\right)$ under different ecological conditions in order to characterize its ecological requirements.

For the purpose of this study geobiocoenological typology was used. It is based on biogeographical differentiation of the landscape by a geobiocoenological approach (Buček and Lacina 1999). This process arises from the theories of Professor A. Zlatník (Zlatník 1976), founder of the Czech school of geobiocoenology. This theory is based on the hypothesis of the unity of natural and human-influenced communities. The type of the geobiocoene represents a unit of a topical level, created by the typization of analyzed basic segments of nature. It is a natural unit associating contemporary natural segments of one type of geobiocoenosis with all changed segments arisen on the areas of the same type of permanent ecological conditions (Buček and Lacina 1999).

\section{MATERIALS AND METHODS}

\section{Study area and experimental plots}

Q. polycarpa was studied in protected areas of the Training Forest Enterprise Masaryk Forest Krrtiny which is an organisational part of Mendel University in Brno. The enterprise is located in the south-east of the Czech Republic (figure 1). 12 protected areas were chosen for the purpose of this study due to the rich occurrence of the studied species in natural stands that had been reported from there (Matula 2007) (table 1). The approximate age of the forests was estimated between 100 and 150 years (by calculating tree rings growth on the cut trees). Besides Quercus polycarpa Schur, the studied forests were composed of Quercus dalechampii Ten., Q. petraea (Matt) Liebl., Carpinus betulus L., Acer campestre L., and Fagus sylvatica L. 
Fig. 1: Location of the Training Forest Enterprise Masaryk Forest Krrtiny, south-east of the Czech Republic (a) and locations of studied protected areas within the Training Forest Enterprise (b).

a)

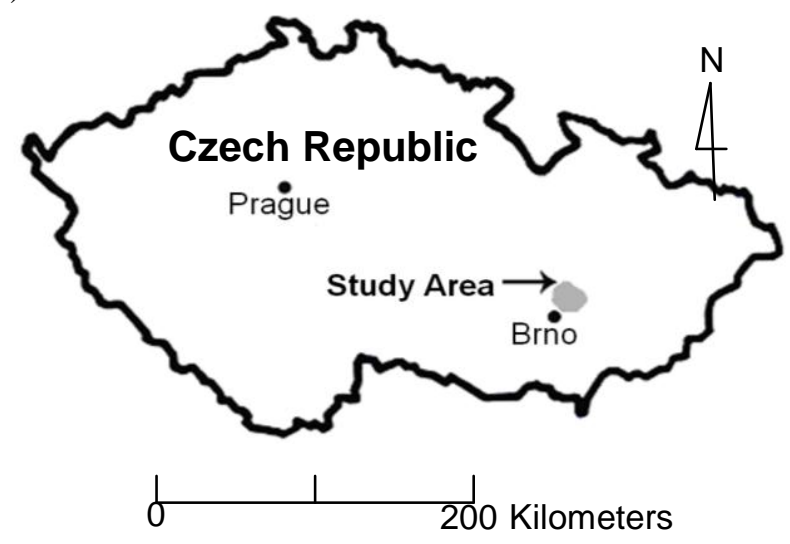

b)

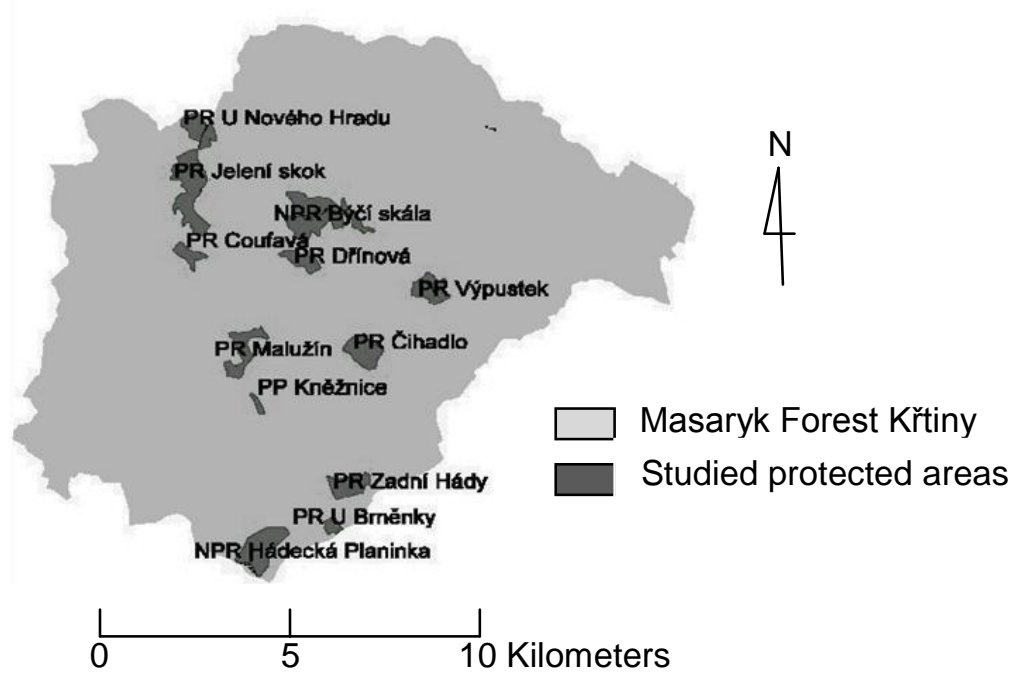

The average annual temperature of the area ranges from 7.0 to $9.5^{\circ} \mathrm{C}$, the average annual precipitation varies between 450 and $550 \mathrm{~mm}$. Brno's igneous rock forms bedrock of great part of the area. The most common soils on this kind of bedrock are cambisoles; lithosols and rankers are less often. A limestone is the second less often type of bedrock in the area which is covered by rendzina soils.

There were 65 fixed area square plots set up in stands with $Q$. polycarpa in the main storey. The method of choosing plot location and size was according to Ellenberg (1956). Each plot was of the size of $400 \mathrm{~m}^{2}$ and the vegetation, structure and composition across each plot was homogenous. This could be easily fulfilled as all research sites were located in areas with large forest stands.

First the representation of $Q$. polycarpa was evaluated on a plot by identifying all oak species. After that, tree height, diameter at breast height (the height of $1.30 \mathrm{~m}(\mathrm{DBH})$ ), 
setting of living crown and crown diameter were measured. The height measurements were carried out with SILVA ClinoMaster, the diameter then with a diameter tape. The crown diameter was measured in two directions: south- north and west-east. The average of both measurements was used as a final crown diameter and was used for further analysis. Natural conditions of every plot were assessed. For this purpose ecological sub-units of geobioceonological forest typology of Zlatník (1976) modified by Buček and Lacina (1999) were used. Based on present soil type, bedrock, climate data and floristic composition every plot was assigned to a certain altitudinal vegetation zone and certain trophic and hydric ranges.

\section{DATA ANALYSIS}

Occurrence in different ecological ranges was calculated as a relative representation of $Q$. polycarpa out of all oak trees. Means of tree height, DBH, life crown base setting and crown diameter were calculated within each ecological range. Except for the species representation, it was not possible to run statistical analysis for altitudinal vegetation zones due to insufficient number of individuals in the $3 \mathrm{rd}$ zone as the vast majority of studied individuals fell into the 2 nd altitudinal vegetation zone.

The normality of the analyzed data was confirmed by the Kolmogorov-Smirnov test ( $\mathrm{p}>$ $0.05)$. In order to find out whether measured characteristics change in different ecological ranges I used simple one-way ANOVA. The significance level was set at $p<0.05$. The variables with ecological ranges were used as independent categorical variables. Measured parameters were used as dependent variables. The null hypothesis was that there is no difference between ecological ranges. When the null hypothesis was rejected conservative Scheffé post-hoc test was run in order to assess which geobiocoenological subunits differ from each other.

\section{RESULTS}

Q. polycarpa has been found in the 2 nd and the 3 rd altitudinal vegetation zones. In the 2nd zone it represented $47.13 \%$ of all oak species; in the 3rd one it was $54.29 \%$, however, the difference was not statistically significant $(\mathrm{F}=1.065531, \mathrm{p}=0.305068)$. As for the trophic ranges, $Q$. polycarpa occurs in almost the whole range. It is a common species from the oligo-mesic (AB) through mesic (B) and meso-basic (BD) to basic (D) range. It has been found with high frequency in all these ecological ranges among which its representation did not statistically differ $(\mathrm{F}=0.557064, \mathrm{p}=0.644952)$. $Q$. polycarpa has also been found in a high number from the 1 st to the 3 rd hydric ranges but its representation did not differ among them either $(\mathrm{F}=3.66984, \mathrm{p}=0.29920)$ (fig. 2$)$. 
Fig. 2: Relative representation of $Q$. polycarpa of all oak species in ecological ranges

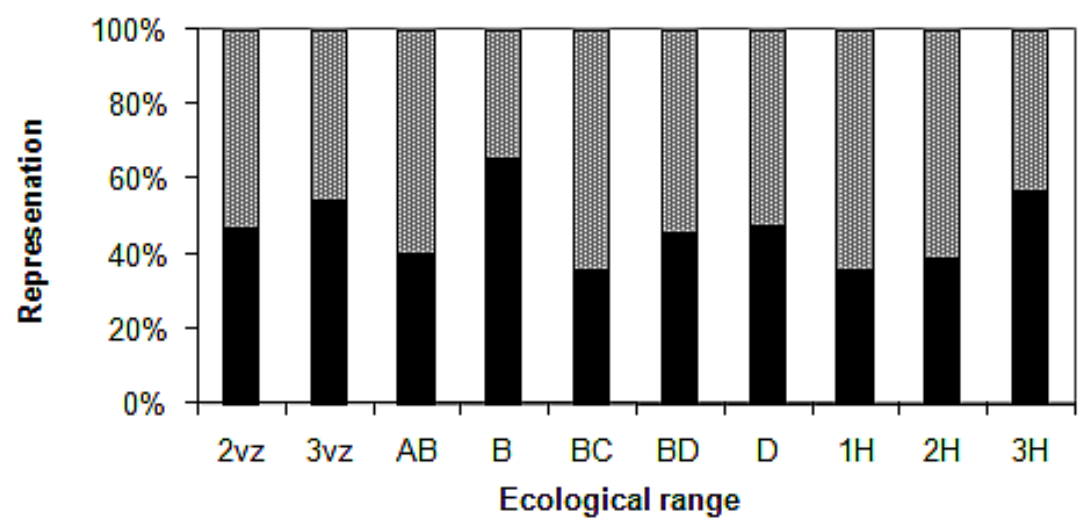

Q. polycarpa aOther Oak Species

Means of stem diameters vary significantly among hydric and trophic ranges $\left(\mathrm{F}_{\text {hydric }}=\right.$ $\left.44,346, \mathrm{p}<0.000001, \mathrm{~F}_{\text {trophic }}=15,591, \mathrm{p}<0.000001\right)$. The biggest difference was found in the hydric ranges. Under driest conditions represented by the range $1 \mathrm{H} Q$. polycarpa reached on average only $18.57 \mathrm{~cm}$ while in the normal hydric range $3 \mathrm{H}$ it had $39.52 \mathrm{~cm}$ on average (fig.3a). The differences among trophic ranges are smaller (fig. 3b), however, there are also a number of significant ones (tab.1). The lowest average value of $28.49 \mathrm{~cm}$ the species reached in the oligo-mesic range $(\mathrm{AB})$; the average biggest diameter of $39.73 \mathrm{~cm}$ occurred in the mesic range (B).

Fig. 3: Average DBH of $Q$. polycarpa within a) hydric and b) trophic ranges. Vertical bars denote 0.95 confidence intervals.

a)

Hydric ranges

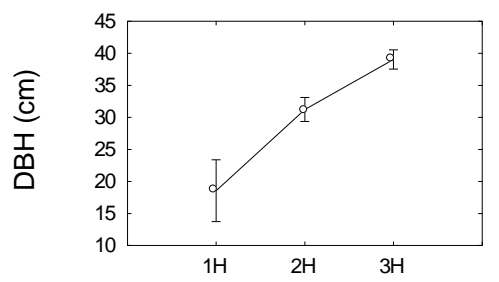

b)

Trophic ranges

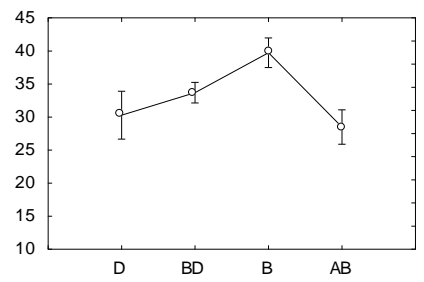


Table 1: P-values between ranges for DBH within a) hydric and b) trophic ranges. Pvalues $p<0,05$ mean there is a statistical difference between two ranges and are highlighted in bold.

a)

\begin{tabular}{|c|ccc|}
\hline $\begin{array}{c}\text { Hydric } \\
\text { range }\end{array}$ & $1 \mathrm{H}$ & $2 \mathrm{H}$ & $3 \mathrm{H}$ \\
\hline $1 \mathrm{H}$ & & $\mathbf{0 . 0 0 0 0 1 3}$ & $\mathbf{0 . 0 0 0 0 0 0}$ \\
$2 \mathrm{H}$ & $\mathbf{0 . 0 0 0 0 1 3}$ & & $\mathbf{0 . 0 0 0 0 0 0}$ \\
$3 \mathrm{H}$ & $\mathbf{0 . 0 0 0 0 0 0}$ & $\mathbf{0 . 0 0 0 0 0 0}$ & \\
\hline
\end{tabular}

b)

\begin{tabular}{|c|cccc|}
\hline $\begin{array}{c}\text { Trophic } \\
\text { range }\end{array}$ & $\mathrm{D}$ & $\mathrm{BD}$ & $\mathrm{B}$ & $\mathrm{AB}$ \\
\hline $\mathrm{D}$ & & 0.408048 & $\mathbf{0 . 0 0 0 3 1 8}$ & 0.889737 \\
$\mathrm{BD}$ & 0.408048 & & $\mathbf{0 . 0 0 0 3 4 7}$ & $\mathbf{0 . 0 1 0 8 7 7}$ \\
$\mathrm{B}$ & $\mathbf{0 . 0 0 0 3 1 8}$ & $\mathbf{0 . 0 0 0 3 4 7}$ & & $\mathbf{0 . 0 0 0 0 0 0}$ \\
$\mathrm{AB}$ & 0.889737 & $\mathbf{0 . 0 1 0 8 7 7}$ & $\mathbf{0 . 0 0 0 0 0 0}$ & \\
\hline
\end{tabular}

Out of all measured parameters, $Q$. polycarpa proved to vary the most in total tree height $\left(\mathrm{F}_{\text {hydric }}=262.27, \mathrm{p}<0.000001 ; \mathrm{F}_{\text {trophic }}=110,48, \mathrm{p}<0.000001\right)$. Quite small trees occurred in the 1 st hydric range where the average height was only $5.59 \mathrm{~m}$ (fig. $4 \mathrm{a}$ ). On the contrary, the highest trees grew in the normal trophic range B (fig. 4b). As table 2a shows, all hydric ranges significantly differ from each other in this respect and the same is for trophic ranges except for BD versus $\mathrm{D}$ which are quite similar (tab. $2 \mathrm{~b}$ ).

Fig. 4: Average height of $Q$. polycarpa within a) hydric and b) trophic ranges. Vertical bars denote 0.95 confidence intervals.

a)

Hydric ranges

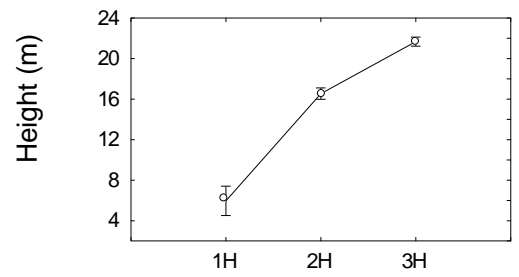

b)

Trophic ranges

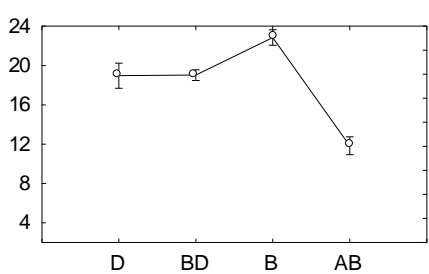


Table 2: P-values between ranges for average height DBH within a) hydric and b) trophic ranges. $P$-values $p<0,05$ mean there is a statistical difference between two ranges and are highlighted in bold.

a)

\begin{tabular}{|c|ccc|}
\hline $\begin{array}{c}\text { Hydric } \\
\text { range }\end{array}$ & $1 \mathrm{H}$ & $2 \mathrm{H}$ & $3 \mathrm{H}$ \\
\hline $1 \mathrm{H}$ & & $\mathbf{0 . 0 0 0 0 0 0}$ & $\mathbf{0 . 0 0 0 0 0 0}$ \\
$2 \mathrm{H}$ & $\mathbf{0 . 0 0 0 0 0 0}$ & & $\mathbf{0 . 0 0 0 0 0 0}$ \\
$3 \mathrm{H}$ & $\mathbf{0 . 0 0 0 0 0 0}$ & $\mathbf{0 . 0 0 0 0 0 0}$ & \\
\hline
\end{tabular}

b)

\begin{tabular}{|c|cccc|}
\hline $\begin{array}{c}\text { Trophic } \\
\text { range }\end{array}$ & $\mathrm{D}$ & $\mathrm{BD}$ & $\mathrm{B}$ & $\mathrm{AB}$ \\
\hline $\mathrm{D}$ & & 0.999853 & $\mathbf{0 . 0 0 0 0 1 4}$ & $\mathbf{0 . 0 0 0 0 0 0}$ \\
$\mathrm{BD}$ & 0.999853 & & $\mathbf{0 . 0 0 0 0 0 0}$ & $\mathbf{0 . 0 0 0 0 0 0}$ \\
$\mathrm{B}$ & $\mathbf{0 . 0 0 0 0 1 4}$ & $\mathbf{0 . 0 0 0 0 0 0}$ & & $\mathbf{0 . 0 0 0 0 0 0}$ \\
$\mathrm{AB}$ & $\mathbf{0 . 0 0 0 0 0 0}$ & $\mathbf{0 . 0 0 0 0 0 0}$ & $\mathbf{0 . 0 0 0 0 0 0}$ & \\
\hline
\end{tabular}

It has been found out that the height of crown setting significantly changes among the ecological ranges $\left(F_{\text {hydric }}=41.204, p<0.000001, F_{\text {trophic }}=22,610, p<0.000001\right)$. As the Table $3 \mathrm{a}$ shows, there are differences among all hydric ranges but differences among trophic ranges were found only between $\mathrm{AB}$ and the other ones (tab. 3b). However, Q. polycarpa had clearly lower crown setting both in the ranges $1 \mathrm{H}$ and $\mathrm{AB}$ (fig. 5).

Fig. 5: Average height of live crown setting within a) hydric and b) trophic ranges. Vertical bars denote 0.95 confidence intervals.

a)

Hydric ranges

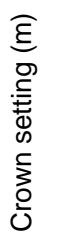

b)

Trophic ranges

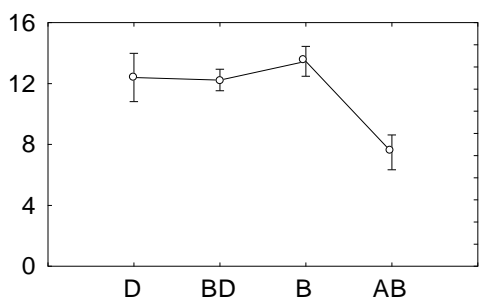


Table 3: P-values between ranges for Average height of live crown setting within a) hydric and b) trophic ranges. P-values $p<0.05$ mean there is a statistical difference between two ranges and are highlighted in bold.

a)

\begin{tabular}{|c|ccc|}
\hline $\begin{array}{c}\text { Hydric } \\
\text { range }\end{array}$ & $1 \mathrm{H}$ & $2 \mathrm{H}$ & $3 \mathrm{H}$ \\
\hline $1 \mathrm{H}$ & & $\mathbf{0 . 0 0 0 0 0 0}$ & $\mathbf{0 . 0 0 0 0 0 0}$ \\
$2 \mathrm{H}$ & $\mathbf{0 . 0 0 0 0 0 0}$ & & $\mathbf{0 . 0 0 0 0 0 6}$ \\
$3 \mathrm{H}$ & $\mathbf{0 . 0 0 0 0 0 0}$ & $\mathbf{0 . 0 0 0 0 0 6}$ & \\
\hline
\end{tabular}

b)

\begin{tabular}{|c|cccc|}
\hline $\begin{array}{c}\text { Trophic } \\
\text { range }\end{array}$ & $\mathrm{D}$ & $\mathrm{BD}$ & $\mathrm{B}$ & $\mathrm{AB}$ \\
\hline $\mathrm{D}$ & & 0.998047 & 0.743819 & $\mathbf{0 . 0 0 0 0 2 8}$ \\
$\mathrm{BD}$ & 0.998047 & & 0.268281 & $\mathbf{0 . 0 0 0 0 0 0}$ \\
$\mathrm{B}$ & 0.743819 & 0.268281 & & $\mathbf{0 . 0 0 0 0 0 0}$ \\
$\mathrm{AB}$ & $\mathbf{0 . 0 0 0 0 2 8}$ & $\mathbf{0 . 0 0 0 0 0 0}$ & $\mathbf{0 . 0 0 0 0 0 0}$ & \\
\hline
\end{tabular}

Differences were also found in the average crown diameter, however, they were not as significant as those of other parameters $\left(\mathrm{F}_{\text {hydric }}=21.941, \mathrm{p}<0.000001, \mathrm{~F}_{\text {trophic }}=9,557, \mathrm{p}<\right.$ 0.000001). There are differences among all hydric ranges (tab. 4a) but a difference among trophic ranges was found only between $\mathrm{AB}$ and the others (tab. 4b). Again, in the ranges $1 \mathrm{~h}$ and $\mathrm{AB} Q$. polycarpa had considerably smaller crowns (fig. 6).

Fig. 6: Average crown diameters of $Q$. polycarpa within a) hydric and b) trophic ranges. Vertical bars denote 0.95 confidence intervals.

a)

Hydric ranges

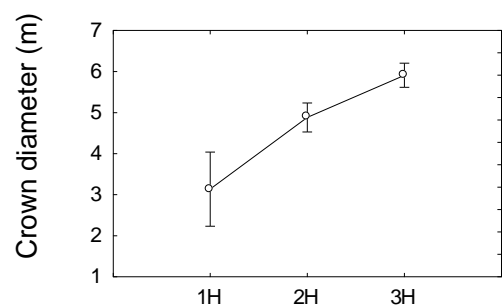

b) Trophic ranges

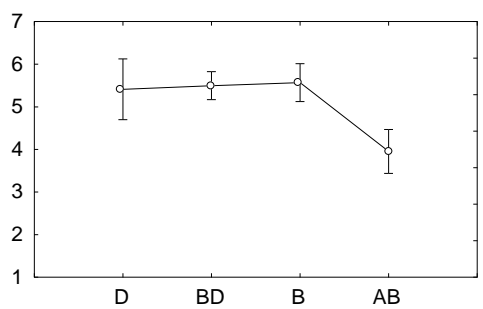


Table 4: P-values between subunits for average crown diameters within a) hydric and b) trophic ranges. $\mathrm{P}$-values $\mathrm{p}<\mathbf{0 , 0 5}$ mean there is a statistical difference between two ranges and are highlighted in bold.

a)

\begin{tabular}{|c|ccc|}
\hline $\begin{array}{c}\text { Hydric } \\
\text { range }\end{array}$ & $1 \mathrm{H}$ & $2 \mathrm{H}$ & $3 \mathrm{H}$ \\
\hline $1 \mathrm{H}$ & & $\mathbf{0 . 0 0 2 1 2 2}$ & $\mathbf{0 . 0 0 0 0 0 0}$ \\
$2 \mathrm{H}$ & $\mathbf{0 . 0 0 2 1 2 2}$ & & $\mathbf{0 . 0 0 0 0 8 4}$ \\
$3 \mathrm{H}$ & $\mathbf{0 . 0 0 0 0 0 0}$ & $\mathbf{0 . 0 0 0 0 8 4}$ & \\
\hline
\end{tabular}

b)

\begin{tabular}{|c|cccc|}
\hline $\begin{array}{c}\text { Trophic } \\
\text { range }\end{array}$ & $\mathrm{D}$ & $\mathrm{BD}$ & $\mathrm{B}$ & $\mathrm{AB}$ \\
\hline $\mathrm{D}$ & & 0.997463 & 0.987431 & $\mathbf{0 . 0 1 5 0 5 3}$ \\
$\mathrm{BD}$ & 0.997463 & & 0.995728 & $\mathbf{0 . 0 0 0 0 2 8}$ \\
$\mathrm{B}$ & 0.987431 & 0.995728 & & $\mathbf{0 . 0 0 0 0 9 9}$ \\
$\mathrm{AB}$ & $\mathbf{0 . 0 1 5 0 5 3}$ & $\mathbf{0 . 0 0 0 0 2 8}$ & $\mathbf{0 . 0 0 0 0 9 9}$ & \\
\hline
\end{tabular}

\section{DISCUSSION}

Q. polycarpa can be considered as an ecologically "plastic" species because it has been found abundant in a number of trophic and hydric ranges. Previous descriptions of $Q$. polycarpa ecology by both Koblížek (1990) and Úradníček et al. (2001) state that it occurs in the warmer parts of the Czech Republic. However, Leandru (1994) reported $Q$. polycarpa from Bulgaria in a relatively cold altitudinal vegetation zone right below the zone of Norway Spruce (Picea abies L.) which indicates that it may grow well in colder areas of the Czech Republic as well. This is in accordance with the findings of this study. Apart from warm parts of the second altitudinal vegetation zone, it has been found and somewhere has been even abundant also in colder climate conditions of the third altitudinal vegetation zone. The reason, why it has not been mentioned from such areas before, is probably due to a lack of information about natural distribution of this species in general and also due to its difficult identification.

The possible range of natural condition in which $Q$. polycarpa occurs may be larger than what has been found out in this study. As for the altitudinal vegetation zones not present in the area, it has been reported from the first warmest altitudinal vegetation zone of the Czech Republic (Koblížek 1990) where it seems to be a common oak species (Matula unpublished data). $Q$. polycarpa may also occur in the oligotrophic range A that has not been found in the studied area but this trophic range is similar to the oligo-mesic one in which the species is common. On the other hand, it is not probable that it would grow in any other than in the 1st, 2nd and 3rd hydric ranges because there is an excess of soil water in the 4th and 5th ones which would not probably allow growing any species of the Quercus petraea aggregate. The slightly lower representation of $Q$. polycarpa in the 2 nd zone compared to the 3rd one is probably caused by higher competition with other oak species such as $Q$. 
dalechampii, $Q$. pubescens or $Q$. cerris which usually do not occur in the 3rd zone (Matula 2007). In the 3rd zone $Q$. polycarpa is usually accompanied only by $Q$. petraea with which it is often mixed.

In general, differences found in hydric ranges are superior to differences in trophic ranges. All hydric ranges differ from each other in all parameters but as for the trophic ranges, only $\mathrm{AB}$ has proved to be considerably different in all parameters. All the measured characteristics have similar distribution in the figures 3, 4, 5 and 6 . They logically show that all the parameters are smallest in the 1st dry hydric range which is typical of little water in the soil layer (Buček and Lacina 1999). It indicates that the available water is the factor which influences the most the stem diameter, height, setting of crown and crown diameter. Nevertheless, height is the parameter which varies the most with changing ecological conditions. It could be considered as a good feature for indicating natural conditions. The crown diameter which turned out to change the least out of all parameters is probably influenced more by other factors such as stand density or light availability. These findings are in accordance with Buček and Lacina (1999) who have used tree height as one of the characteristics for hydric ranges.

\section{ACKNOWLEDGEMENTS}

This study was funded by research project of the Ministry of the Environment SP/2d4/59/07 "Biodiversity and Target Management of Endangered and Protected Species of Organisms in Low and Medium Forests in the Natura 2000 - TARMAG 2000". This publication was also supported by the Institutional Research Plan MSM 6215648902/04/01/01 (the Faculty of Forestry and Wood Technology of Mendel University in Brno) and by IGA of the Faculty of Forestry and Wood Technology of Mendel University in Brno project "Use of genetic information in forest botany, tree physiology, dendrology and geobiocoenology".

\section{REFERENCES}

Buček, A., Lacina, J. (1999). Geobiocenologie II. MUAF in Brno.

Govaerts, R, Frodin, D., G. (1998). World checklist and bibliography of Fagales (Betulaceae, Corylaceae, Fagaceae and Ticodendraceae). Ed. Royal Botanic Gardens. pp 408.

Jovanovič, B. (2000). Dendrologija. Beograd: University of Belgrad.

Cvjetican, R., Paunović, P. (1988). Prilog poznavanju hrastova Fruške Gore. Glasnik Šumarskog fakulteta 70: pp 59-66.

Dostál, J. (1989). Nová květena ČSSR 1. Academia, Prague.

Gančev, I., Bondev, I. (1996). Quercus L. In: Jordanov, D. (Ed.): Flora na Narodna republika Bulgaria III. pp 355. Sofia: Izdatelstvo na Bulgarskata akademija na naukite,

Koblížek, J. (2002). Quercus L. In Kubát, K. et al: Klíč ke květeně České republiky. pp 801801. Academia, Praha,

Koblížek, J. (1990). Quercus L. In: Hejný, S., Slavík, B. (Eds.): Květena ČR 2. pp 21-35. Academia, 
Leandru, V. (1994). Phytogeographical and silvicultural significance of spruce forests in Cozia, Frunti and Ghitu mountains. Revista-Padurilor 109: 2-4.

Magic, D. (1974). Poznáváme dalšie druhy dubov v našich lesoch. Les 6: 244-252.

Magic, D. (1975). Taxonomic remarks of recent research on oaks in the western Carpathiens. Biológia 30: 65-74.

Majer, A. (1989). Subdivisions of durmast oak (Quercus petraea) representation in populations in Hungary. Folia-Dendrologica 16: 179-194.

Manos, P. S., Doyle, J., J. \& Nixon, K. C. (1999). Phylogeny, Biogeography and Processes of Molecular Differentiation in Quercus Subgenus Quercus (Fagaceae). Molecular Phylogenetics and Evolution, Vol. 12, No. 3, pp. 333-349.

Matula, R. (2007). Hodnocení populaci druhů rodu Quercus L. v rezervacích na ŠLP Krrtiny. Dissertation, MUAF in Brno.

Nixon, K. C. (1993). Infrageneric classification of Quercus (Fagaceae) and typification of sectional names. Ann. Sci. For. Suppl. 1, 50: 25 - 34.

Nixon, K., C. (2002). The Oak (Quercus) Biodiversity of California and Adjacent Regions. USDA Forest Service, pp 20.

Požgaj, J., Horvathova, J. (1986). Variability and ecology of species of genus Quercus in Slovak. Variabilita a ekológia druhov rodu Quercus L. na Slovensku. VEDA, Bratislava, pp 151.

Schwarz, O. (1936). Monographie der Eichen Europas und des Mittelmeergebietes. Dahlem bei Berlin, pp 1-160.

Úradníček, L., Maděra, P., Tichá, S. \& Koblížek, J. (2001). Dřeviny české republiky. Matice lesnická, Písek.

Zlatník, A. (1976). Lesnická fytocenologie. Prague: SZN, pp. 495. 